\title{
Etyczne aspekty wykorzystywania zwierząt w procedurach doświadczalnych
}

\author{
Ethical Aspects of Using Animals in Experimental Procedures
}

\author{
Zuzanna Gądzik \\ Instytut Nauk Prawnych, Katolicki Uniwersytet Lubelski Jana Pawła II \\ ORCID: https://orcid.org/0000-0002-9121-4658 • zuzanna.gadzik@kul.pl \\ Zgłoszono: 12.11.2020; zrecenzowano: 4.01.2021; zaakceptowano do druku: 14.01.2021
}

\begin{abstract}
Streszczenie: Artykuł dotyczy analizy aspektów etycznych związanych z wykorzystywaniem zwierząt w procedurach doświadczalnych - w kontekście zadawania im bólu lub cierpienia. Wyniki powyższych procedur mogą z jednej strony mieć bowiem znaczenie dla rozwoju nauki (m.in. nauk medycznych i weterynaryjnych), techniki czy przemysłu, z drugiej natomiast wiążą się niejednokrotnie z bólem lub cierpieniem żywych organizmów, mają negatywny wpływ na ich zdrowie lub nawet życie. Tematyka ta stanowi przedmiot dyskusji naukowej oraz próby znalezienia kompromisu pozwalającego na uzyskiwanie wiarygodnych wyników badań oraz wyeliminowania lub przynajmniej ograniczania negatywnych następstw dla zwierząt w nich wykorzystanych. Artykuł obejmuje zestawienie i charakterystykę poglądów zwolenników i przeciwników przeprowadzania doświadczeń na zwierzętach. W jego ramach pochylono się nad zagadnieniami stanowisk altruistycznych i egoistycznych, szowinizmu gatunkowego oraz tzw. zasad 3R (replacing, reducing, refining). Aktualność artykułu wynika przede wszystkim z wejścia w życie ustawy z 15 stycznia 2015 r. o ochronie zwierząt wykorzystywanych do celów naukowych lub edukacyjnych, uchylającej ustawę z 21 stycznia 2005 r. o doświadczeniach na zwierzętach i regulującej na nowo kwestie związane z możliwością wykorzystywania żywych zwierząt w procedurach doświadczalnych narażających je na ból lub cierpienie.
\end{abstract}

Słowa kluczowe: zwierzęta, ochrona, etyka, procedury doświadczalne

\begin{abstract}
This article deals with an analysis of the ethical aspects of using animals in experimental procedures - in the context of causing animals, pain or suffering. It covers the compilation and characterisation of the views of supporters and opponents of conducting experiments on animals. On the one hand, the findings of the above procedures may be important for the development of science (including medical and veterinary sciences), technology or industry, whilst on the other hand, they are often associated with pain or the suffering of living organisms, and have a negative impact on their health, or even life. This topic is the subject of scientific and ethical discussion, and attempts to find a compromise, that would allow the acquisition of reliable test results, and eliminate, or at least, reduce the negative consequences for animals used in them. The article refers to issues of altruistic and egoistic positions, species chauvinism, and the so-called $3 R$ principles (replacing, reducing, refining). The article is primarily due to the entry into force of the Act of the $15^{\text {th }}$ of January, 2015, on the protection of animals used for scientific or educational purposes, repealing the existing Act of the $21^{\text {st }}$ of January, 2005 , on animal experiments, and re-regulating issues related to the viability of using live animals in experimental procedures, exposing them to pain or suffering.
\end{abstract}

Keywords: animals, protection, ethics, experimental procedures 


\section{Wstęp}

Wykorzystywanie zwierząt w procedurach doświadczalnych uznawane jest za działanie kontrowersyjne, stanowiące od kilkuset lat przedmiot dyskusji i sporów. Przemiany społeczne, szybszy rozwój nauki i techniki oraz wiążące się z nimi zmiany w obowiązujących przepisach prawa, dotyczące ochrony zwierząt - w tym także zwierząt doświadczalnych, prowadzą do tego, iż polemika dotycząca zasadności wykorzystywania zwierząt $w$ procedurach doświadczalnych jest niezmiennie aktualna. Podkreśla się niezbędność badań na zwierzętach jako na organizmach żywych (m.in. w medycynie, weterynarii, przemyśle etc.), dzięki czemu możliwe jest uniknięcie analogicznych badań na człowieku.

Z drugiej jednak strony zwraca się uwagę na niehumanitarny aspekt procedur doświadczalnych, w ramach których wykorzystuje się zwierzęta. Nawet przeprowadzenie ich w sposób zgodny z wymogami prawa wiąże się bowiem z zadaniem zwierzęciu bólu, cierpienia, narażeniu je na strach, trwałe uszczerbki na zdrowiu, a także śmierć. Powyższe elementy zawarte zostały w definicjach ustawowych doświadczenia na zwierzętach zawartych m.in. w przepisach ustawy z 21 sierpnia 1997 r. o ochronie zwierząt (t.j. Dz.U. z 2020, poz. 638), ustawy z 21 stycznia 2005 r. o doświadczeniach na zwierzętach (Dz.U. Nr 33, poz. 289 ze zm.), ustawy z 15 stycznia 2015 r. o ochronie zwierząt wykorzystywanych do celów naukowych lub edukacyjnych (t.j. Dz.U. z 2019 r., poz.1392). Warto zwrócić w tym kontekście uwagę, iż ustawodawca - wprowadzając odpowiednie środki ochrony zwierząt - podkreślił, że ich zastosowanie ma na celu przeciwdziałanie nie tylko dolegliwościom o charakterze fizycznym - powstającym pod wpływem bodźców uszkadzających tkankę bądź zagrażających jej uszkodzeniem (w postaci bólu), lecz także tym związanym z negatywnymi stanami psychicznymi lub fizycznymi i emocjonalnymi (przez które rozumieć należy cierpienie zwierzęcia). Przyjęcie takiego kryterium stanowi podstawę ochrony humanitarnej zwierząt (Gądzik 2018, 121).

Na gruncie prowadzonej dyskusji zagadnienie wykorzystywania zwierząt w procedurach doświadczalnych stało się przedmiotem zainteresowania etyki - w szczególności ustalenia i zdefiniowania co $\mathrm{w}$ ramach tak podjętych działań należy uznać za moralnie dobre bądź złe (Chmurzyński 1995, 39). Negując bowiem zasadność ich przeprowadzania, podnosi się, iż podstawą podjęcia takiej dyskusji jest przyznanie zwierzętom doświadczalnym zdolności do odczuwania bólu lub cierpienia oraz rozważenie, czy zadawanie im go można uznać za dopuszczalne. Wśród najważniejszych argumentów przeciwników powyższych działań wymienia się bowiem przede wszystkim niehumanitarny charakter takich procedur.

Należy również zaznaczyć, że aktualność toczącej się w tym zakresie dyskusji wynika obecnie w głównej mierze z wprowadzenia do polskiego porządku prawnego ustawy z dnia 15 stycznia 2015 r. o ochronie zwierząt wykorzystywanych do celów naukowych lub edukacyjnych. Powyższy akt prawny, wchodząc w życie w dniu 27 maja 2015 r., znowelizował dotychczasowe uregulowania związane z ochroną prawną zwierząt wykorzystywanych w procedurach doświadczalnych - w pewnym zakresie ograniczając tę ochronę. Co więcej, ustawa ta była już kilkakrotnie nowelizowana - przede wszystkim w celu dostosowania standardów przeprowadzania procedur doświadczalnych z wykorzystaniem zwierząt do wymogów prowadzenia badań naukowych i prac rozwojowych w rozumieniu przepisów ustawy z dnia 20 lipca 2018 r. - Prawo o szkolnictwie wyższym i nauce (t.j. Dz.U. z 2020 r., poz. 85). O dynamice i potrzebie dalszych zmian świadczy również zgłoszenie kolejnego projektu nowelizacji powyższej ustawy - związanego z ograniczeniem ilości przeprowadzanych testów oraz zapewnienia w stosunku do zwierząt doświadczalnych odpowiednio wczesnych i humanitarnych metod zakończenia procedur (Rada Ministrów 2020). 
Tworzenie przepisów prawa jest zjawiskiem dynamicznym. Musi być ono bowiem odpowiednio dostosowane do zmieniających się standardów i potrzeb - o charakterze społecznym, ekonomicznym, naukowym czy gospodarczym. Konieczne staje się niejednokrotnie znalezienie kompromisu pomiędzy pozornie sprzecznymi wartościami. $Z$ tego też względu ustawodawcy przypisuje się przymiot racjonalności w tworzeniu obowiązujących norm i przepisów. Wykorzystywanie zwierząt do celów naukowych lub edukacyjnych jest doskonałym przykładem potwierdzającym tę tezę. Z jednej bowiem strony na ustawodawcy ciąży obowiązek unormowania sposobu i zakresu przeprowadzania procedur doświadczalnych - dla uzyskania wiarygodnych i mających wartość poznawczą wyników, z drugiej natomiast, uwzględniając wymóg dereifikacji zwierząt - stworzenia warunków humanitarnego ich traktowania. Z uwagi na to, na etapie projektowania przepisów, ustawodawca posiłkuje się specjalistycznymi opiniami wydanymi m.in. przez przedstawicieli nauk medycznych, weterynaryjnych, etyków etc. Wziąwszy pod uwagę zakres niniejszego artykułu, oceniając możliwość wykorzystywania zwierząt dla celów naukowych lub edukacyjnych, konieczne jest ogólne omówienie poglądów dotyczących dopuszczalności zadawania zwierzętom bólu lub cierpienia i wskazania, w jaki sposób zastosowana w ich ramach argumentacja wpłynęła na przyjmowaną w praktyce i skodyfikowaną dopuszczalność narażania zwierząt na negatywne bodźce $\mathrm{w}$ ramach procedur przeprowadzanych $\mathrm{z}$ ich udziałem. Co do zasady, w ramach takich stanowisk wyróżnia się obejmujące względy "altruistyczne" (dotyczące zwierzęcia) oraz „egoistyczne” (dotyczące człowieka), w skład których weszły pobudki osobiste i pragmatyczne (Smaga 2010, 110).

\section{Ochrona zwierząt - stanowisko altruistyczne}

Pierwsza grupa poglądów oparta została na inspiracji światopoglądami religijnymi oraz wynikającej z nich wrażliwości moralnej.
Zgodnie z nią uznano podobieństwo zwierząt do ludzi, a co za tym idzie założono, że mają one podobne potrzeby i mogą cierpieć w sposób analogiczny (Chmurzyński 1995, 39; Masson i McCarthy 1999, 52). Wyznawcy niektórych religii, szczególnie starożytnych, wierzyli, iż zwierzętom - jako równym ludziom - można przypisać wszystkie cechy typowe dla naszego gatunku. Często uznawano je wręcz za istoty boskie, bądź stanowiące uosobienie bóstwa, co skutkowało również ich szczególną ochroną (Białocerkiewicz 2005, 77; Waldau 2011, 105). Szczególny przejaw kultu zwierząt (zoolatrii) stanowi religia Starożytnego Egiptu. Bogów egipskich przedstawiano zwykle jako ludzi ze zwierzęcymi głowami (np. Sechmet - kobieta z głową lwa, Horus - mężczyzna z głową sokoła etc.). Szczególnym kultem cieszyły się także zwierzęta utożsamiane z danym bóstwem (np. koty, krokodyle, skarabeusze etc.). Podobne formy czci można było spotkać również w religiach starożytnego Rzymu, Grecji, Indii etc. (Hallam 1999, 11; Bator 2004, 174; Achtelik 2007, 14).

Obecnie, najszerszy zakres ochrony zwierząt - w rozumieniu altruistycznym - opiera się na religiach uznających reinkarnację (w szczególności w hinduizmie, buddyzmie). W buddyzmie prócz argumentu związanego z reinkarnacją podnosi się również, iż wszystkie istoty żyjące stanowią jedność i żadna z nich w stosunku do pozostałych nie jest drugorzędna. Człowiek nie posiada wśród nich pozycji dominującej. Zabronione jest szkodzenie żywym istotom i ich zabijanie - w trakcie odbierania komuś życia powstaje bowiem karma, która stanowi podstawę wszelkich wojen i chorób. Zachowanie to zostało uznane za czyn o charakterze demonicznym. Uniwersalnym celem buddyzmu jest więc praca nad likwidacją cierpienia wszystkich stworzeń - nie tylko istot ludzkich (Janik 2012, 84; Epstein 2020). Zgodnie z tym poglądem dusza ludzka po śmierci może ponownie wcielić się w nowy byt fizyczny, zdeterminowany jej postępowaniem w czasie swojego życia - w tym może przybrać również kształt zwierzęcy 
(Donimirski 1989, 21). Gwarantuje to obowiązek opieki człowieka nad zwierzęciem i przyjaznego stosunku do całej przyrody. Człowiek nie powinien krzywdzić, ani zabijać żadnego żywego stworzenia, mając świadomość, że w każdej takiej istocie może znajdować się ludzka dusza, a w związku z tym każde takie stworzenie może cierpieć na równi z nim. Co więcej, musi mieć on również świadomość, że podobny los może spotkać przy następnym wcieleniu także i jego (Kluba 1965, 159; Tokarczyk 1986, 210; Chmurzyński 1995, 41; Białocerkiewicz 2005, 90). Jednocześnie należy wspomnieć, iż karą za złe i niegodne życie jest powtórne narodzenie się w postaci zwierzęcej, co w porównaniu z życiem człowieka może być uznane za poniżające (Waldau 2011, 108).

Wśród zwolenników stanowiska altruistycznego podstawą głoszonego przez nich poglądu jest przekonanie o równości ludzi i zwierząt, ze względu na zdolność do odczuwania przez nie bólu lub cierpienia - m.in. z uwagi na podobną do ludzkiej budowę układu nerwowego odpowiadającego za odbieranie różnych bodźców (Paton 1997, 13; Matheny 2011, 29). Teoria ta znajduje swoje uzasadnienie na gruncie fizjologii. Podczas działania bodźców bólowych uwalniają się w tkankach pewne bólotwórcze substancje chemiczne, które drażnią wolne zakończenia nerwowe (np. histamina, serotonina, acetylocholina etc.). Na podstawie zmian zachodzących w środowisku wewnętrznym organizmu zwierzęcego, które są podobne do reakcji w analogicznej sytuacji w organizmie człowieka, można więc uznać, iż zwierzęta odczuwają ból podobnie jak ludzie (Bieguszewski 2003, 64; Załucki i Zawadzki 2005, 51). Na podstawie teorii biocentrycznej człowiek nie stoi ponad przyrodą - stanowi jej integralną część i funkcjonuje w jej ramach na równi z innymi zwierzętami. Poprzez równy z człowiekiem status egzystencjalny m.in. w związku z podobną zmysłowością, odczuwaniem cierpienia, psychizmem, wrażliwością etc. - świat przyrody nabywa równe z nim prawa do szacunku i ochrony (Łapiński 2002, 154). Nie można uznać jego życia za bardziej wartościowe tylko z uwagi, iż należy do gatunku ludzkiego (Piątek 1998, 75; Majewski 2000, 371). Z zasady równości wynika więc równe poszanowanie człowieka i zwierząt - niezależnie od rozumności, która nie wiąże się w żaden sposób ze zdolnością do odczuwania bólu i cierpienia lub określonych cech fizycznych (Singer 1980, 53; Paton 1997, 42; Singer 2004, 254; Pietrzykowski 2007, 80; DeGrazia 2011, 63). $\mathrm{Z}$ uwagi na to, że ból i cierpienie są złem samym w sobie, a przy tym nie są odczuciem, które można przypisać jedynie człowiekowi, za zasadę powszechnie obowiązującą należy uznać zakaz wszelkich aktów okrucieństwa i przemocy (Feinberg 1980, 24). Na marginesie należy jednak podkreślić, że przeciwnicy tego poglądu zarzucają mu, iż zacieranie różnic pomiędzy światem ludzi a zwierząt prowadzi w rzeczywistości do dekonstrukcji idei humanizmu, która stanowi podstawę współczesnej demokracji, wolności oraz praw człowieka (Zięba 1993a, 29; Zięba 1993b, 22; Ferry 1995, 24; Białocerkiewicz 2005, 85; Białocerkiewicz 2007, 100).

Według twórców utylitaryzmu zadawanie bólu lub cierpienia jakiejkolwiek istocie będzie dopuszczalne jedynie wtedy, gdy zapobiegnie to większym dolegliwościom (Przała 2005, 66). Przeciwny pogląd prowadzi bowiem do tzw. szowinizmu gatunkowego, a więc przypisywania sobie w ramach własnego gatunku prawa do uciskania istot, które do gatunku tego nie należą. W ramach tego poglądu wyraża się zgodę, aby interesy własnego gatunku były nadrzędne w stosunku do większych interesów członków innych gatunków. Szowinizm gatunkowy, obok m.in. rasizmu i seksizmu, jest jedną z podstawowych form współczesnej dyskryminacji (Ryder 1980, 43; Dobrucka 1995, 91; Piątek 1998, 116; Ryder 2011, 130; Woleński 2012, 23).

Innym argumentem przemawiającym za humanitarnym traktowaniem zwierząt m.in. w trakcie procedur doświadczalnych jest przyznanie im statusu podmiotów życia, a więc istot, które mają przekonania i dążenia, są zdolne do odczuwania - w tym również bólu i przyjemności, mają pamięć 
i poczucie przyszłości. Przedstawicielem powyższego poglądu jest przede wszystkim Tom Regan. Zaznaczyć jednak należy, że krąg zwierząt, które Regan uznawał za podmioty życia, został przez niego zawężony (z uwagi na podobieństwo tych zwierząt do ludzi - w ich zachowaniu, budowie anatomicznej oraz wspólnych ewolucyjnie korzeniach) do określonych organizmów ssaków, ptaków i ryb (Regan 2004, 60; Gzyra 2012, 55). Przypisać można im również zdolność do zachowania pozwalającego na realizację własnych celów i umiejętność ich wyboru. Podmioty życia charakteryzują się stałą psychofizyczną indywidualnością i dokonywaniem subiektywnej oceny tego, co jest dla nich zdarzeniem pozytywnym bądź negatywnym (Regan 2004, 243). Niedopuszczalne jest ich traktowanie w sposób utylitarny - jako narzędzi do realizacji ludzkich celów i uzależniając ich pozycję jedynie od jakości ich przeżyć. Samoistna wartość przysługuje wszystkim istotom w sposób równy i nie jest w żaden sposób uzależniona od jakości ich życia i rejestrowanych doznań (Regan 2004, 236).

Jako jednostki posiadające samoistną wartość zwierzęta muszą być traktowane z poszanowaniem tej godności (Regan 2004, 248). Wynika z tego, iż uprawnienia zwierzęcia do życia, wolności, niezadawania mu bólu lub cierpienia etc., jako mające wartość równą $\mathrm{z}$ analogicznymi uprawnieniami ludzkimi, nie powinny być naruszone. W szczególności dotyczy to wykorzystywania zwierząt w celach naukowych, rozrywkowych lub spożywczych (Regan 2004, 393; Piątek 1998, 126; Michna 2001, 5; Pietrzykowski 2007, 90; Gzyra 2012, 45; Francuz 2012, 54).

\section{Ochrona zwierząt - stanowisko egoistyczne}

Stanowiska egoistyczne wpisują się w nurt antropocentryzmu aksjologicznego, zgodnie z którym człowiek stanowi wartość bezwzględną i jest punktem wyjścia do pozostałych wartości (Szabała 1998, 13). Swoiste znaczenie ma więc tylko to, co można uznać za przydatne dla człowieka. Szacunek dla przyrody i traktowanie zwierząt w sposób humanitarny wynika z dbałości człowieka o jego odczucia i ma swoje źródło w ludzkiej godności (Bonenberg 1992, 15; Majewski 20oo, 365). Zgodnie ze stanowiskiem egoistycznym dopuszczalne jest zadawanie zwierzętom bólu lub cierpienia i pozbawianie ich życia jedynie w sytuacjach, gdy jest to konieczne oraz w sposób, który należy ograniczyć do niezbędnego minimum (Bentham 1958, 418; Hoff 1980, 63). Przedstawiciel antropocentryzmu - John Passmore podnosił ponadto, że ludzie nie moga zostać zrównani z innymi istotami żywymi, gdyż wpłynęłoby to na postęp cywilizacyjny. Jednocześnie z uwagi na zagrożenia wynikające z dewastacji środowiska postulował ochronę przyrody dla interesów człowieka i przyszłych pokoleń (El-Jai 2008, 39). Zwierzęta doświadczalne mają za zadanie służyć człowiekowi w postępie cywilizacyjnym i zaspokajać jego potrzeby (El-Jai 2008, 40).

Przez stanowisko egoistyczne w znaczeniu osobistym rozumieć należy pogląd, zgodnie z którym przeciwdziałanie zadawaniu bólu lub cierpienia zwierzętom ma na celu wzbudzenie w człowieku pewnego rodzaju wrażliwości, dzięki której nie będzie on nikogo krzywdził. Uznaje się bowiem, iż okrutne zachowanie w stosunku do zwierząt może prowadzić w dalszej perspektywie, w wyniku zachodzących przez to zmian w ludzkim charakterze, do zadawania bólu lub cierpienia także innym ludziom. W celu wychowania ludzi dobrych i wrażliwych należy zadbać o ich pozytywny stosunek do zwierząt (Kant 1953, 62; Tomasz z Akwinu 1985, 231; Locke 1959, 119; Chmurzyński 1995, 40; Vetulani 1995, 10; Piątek 1998, 108; Smaga 2010, 111). Stanowisko to zdecydowanie odrzuca T. Regan, twierdząc, iż okrutne traktowanie zwierząt stanowi zło samo w sobie i nie ma żadnego znaczenia fakt, czy zachowanie to ma jakikolwiek wpływ na zmiany zachodzące w psychice i postępowaniu takiego człowieka (Regan 1980, 94; Schopenhauer 2004, 121). W nurt ten można również wpisać stanowisko reprezentowane przez 
św. Franciszka z Asyżu. W każdym stworzeniu widział on bowiem dobroć Boga i jako mające wspólne z nim źródło uznawał je jako członka swojej rodziny. Nie tolerował krzywdy wyrządzanej żadnej istocie żyjącej, a w swoim nauczaniu nawoływał do zgodnej koegzystencji ze światem przyrody - według niego wojny i wszelkie naruszenia prawa mają swoje źródło w niewłaściwym traktowaniu zwierząt (Dubinin 1998, 105; Smaga 2010, 22; Kozłowski 2012, 144).

Pogląd egoistyczny w znaczeniu pragmatycznym opiera się natomiast na założeniu, iż zwierzę służące człowiekowi w sposób bezpośredni lub pośredni (poprzez dostarczanie mleka, mięsa, własnego towarzystwa etc.) powinno żyć godnie - bez narażania je na niepotrzebny ból, cierpienie lub stres - i takie warunki należy mu w miarę możliwości zapewnić. Zwierzę odczuwające ból lub cierpienie nie może bowiem wypełniać swoich obowiązków względem człowieka, bądź wypełnia je w sposób niezadowalający, np. podnosi się, że mięso zestresowanych zwierząt jest niesmaczne i może zawierać trujące enzymy, które wytwarzają się w jego organizmie przed śmiercią; prócz tego niehumanitarne traktowanie zwierząt m.in. w trakcie ich transportu prowadzić może do ich przedwczesnej śmierci i chorób, co zmniejsza ilość i jakość surowców przeznaczonych do obrotu (Chmurzyński 1995, 40; Olędzka 1995, 111; Dzierżyńska-Cybulko 1981, 53; Prost 2006, 56; Smaga 2010, 111). Przesłanki te można odnieść również do zwierząt doświadczalnych - niewłaściwe traktowanie może prowadzić do uzyskania błędnych wyników przeprowadzanego doświadczenia. W związku z tym konieczne jest zapewnienie zwierzętom pewnego standardu, który zapewni im odpowiednią wydajność (pragmatyzm bytowy) (Smaga 2010, 111). W ramach omawianego poglądu podnosi się również, iż humanitarne traktowanie zwierząt jest zasadą uznawaną powszechnie przez opinię publiczną, a nieprzestrzeganie tej zasady wiąże się z potępieniem ze strony społeczeństwa (pragmatyzm społeczny) (Smaga 2010, 111).
Obok powyższych poglądów akceptujących ochronę zwierząt przed bólem i cierpieniem - w pełnym bądź w ograniczonym zakresie - należy wspomnieć również o stanowisku przeciwnym, charakteryzującym się obojętnością wobec cierpień zadawanych zwierzętom. Zgodnie z niektórymi z nich ból zwierząt jest jedynie pozorny, gdyż jako istoty pozbawione duszy nie są one zdolne do jakiejkolwiek wrażliwości - są jedynie maszynami i automatami (Lazari-Pawłowska 1976, 237; Kartezjusz 1994, 42; Singer 2004, 271). Pogląd taki podzielali m.in. Francis Bacon, Thomas Hobbes, John Locke, Immanuel Kant etc. (Liszewski i Zduńczyk 2013, 15). W innym miejscu podnosi się także, iż zwierzęta są pozbawione świadomości, a co za tym idzie, nie zdają sobie sprawy z własnego bólu i cierpienia - dlatego dopuszczalna jest realizacja wszelkich celów, do których niehumanitarne traktowanie zwierząt stanowi środek (Carruthers 1989, 268; odmiennie: Griffin 2004, 34). W przypadku zwierząt wykorzystywanych w procedurach doświadczalnych bolesne metody wiwisekcji wywodziły się z nowego podejścia do świata, w którym człowiek, jako byt dominujący, ma zawładnąć i nie musi liczyć się z dobrostanem zwierząt i minimalizacją odczuwanych przez nie bólu lub cierpień (El-Jai 2008, 38).

\section{Zasadność poddawania zwierząt procedurom doświadczalnym}

Odnosząc się bezpośrednio do argumentów przemawiających za zasadnością lub bezzasadnością podejmowania procedur doświadczalnych z wykorzystaniem zwierząt, w pierwszej kolejności należy wspomnieć, iż za ich przeprowadzaniem przemawiają z całą pewnością odkrycia naukowe, które zostały dokonane dzięki poddaniu zwierząt odpowiednim badaniom - zarówno z zakresu anatomii, medycyny, weterynarii, techniki etc. Ich podstawową wartością była możliwość uniknięcia poddawania ludzi analogicznym procedurom, przy jednoczesnym osiąganiu podobnych rezultatów. Zwolennicy wykorzystywania zwierząt $\mathrm{w}$ procedurach doświadczalnych podnoszą 
bowiem, iż nie ma zasadniczych różnic fizjologicznych pomiędzy zwierzętami laboratoryjnymi a człowiekiem - w obu przypadkach ich organizmy wydzielają bowiem z komórek nerwowych obwodowego i ośrodkowego układu nerwowego analogiczne przekaźniki chemiczne, dzięki którym reagują podobnie na zakażenie lub uszkodzenie tkanek (Botting i Morrison 1997, 68; Paton 1997, 174).

Ponadto wykorzystanie zwierząt w procedurach doświadczalnych, w szczególności w zakresie działalności edukacyjnej, stanowi często jedyną formę osiągnięcia przez studentów odpowiedniej, specjalistycznej wiedzy teoretycznej i praktycznej z zakresu sposobu funkcjonowania organizmu, bądź poznania jego anatomicznej budowy. Prowadzi to także do nabycia w tego rodzaju praktykach biegłości ograniczającej ilościowe oraz jakościowe rozmiary bólu lub cierpienia zarówno u ludzi, jak i zwierząt w związku z wykonywaniem przez uczestniczących zabiegów ratowniczych i leczniczych (Koehler 1981, 22; Majewski 2002, 229; Smaga 2010, 178 i podana tam literatura). Co więcej, wśród argumentów przemawiających za dopuszczalnością wykorzystywania zwierząt w procedurach doświadczalnych podnosi się, iż wiedza uzyskana w ramach podejmowanych czynności, nawet jeżeli nie zostaje bezpośrednio wykorzystana, umożliwia poszerzenie stanu nauki o nowe wiadomości, które mogą być użyte w przyszłości. Podkreśla się bowiem, że głębsze poznanie mechanizmów życia umożliwia manipulowanie metabolizmem organizmu oraz oddziaływanie na jego aparat genetyczny, co w dalszej kolejności może prowadzić do eliminacji źródła określonych chorób (Kasicki 1995, 260).

Z drugiej strony, przeciwnicy wykorzystywania zwierząt w procedurach doświadczalnych poza oczywistym argumentem dotyczącym okrucieństwa podczas podejmowanych w ich ramach czynności, podnoszą również, iż doświadczenia z wykorzystaniem zwierząt stanowią niezmiennie niepewną formę uzyskiwania wyników prowadzonych badań. Wynika to przede wszystkim z różnic między gatunkami, które mogą prowadzić do otrzymania odmiennych rezultatów niż miałoby to miejsce $\mathrm{w}$ przypadku poddania analogicznym badaniom przedstawicieli innego gatunku (w tym człowieka). Układy wewnętrzne każdego organizmu powiązane są bowiem skomplikowaną siecią zależności - często zatem bodziec oddziałujący na dany narząd wewnętrzny zmienia całą fizjologię badanego osobnika, w sposób którego nie sposób przewidzieć lub w pełni wyjaśnić. Odmienne u różnych organizmów są także reakcje na określone substancje chemiczne i reakcje na bodźce zewnętrzne (Bernard i Kaufman 1997, 62; Smaga 2010, 167; Mroczkowski i Frieske 2014, 10). Wśród przykładów takich rozbieżności wymienia się m.in.: testowany na zwierzętach i na tej podstawie uznany za bezpieczny lek przeciwko biegunce - Clioquino, który oślepił lub sparaliżował dziesiątki tysięcy ludzi, a wielu zabił; lek przeciwpadaczkowy - Taltrimida testowany na zwierzętach u ludzi wzmagał napady padaczkowe; lek przeciw artretyzmowi - kwas fenklozydowy - nie szkodzi wątrobie psa, natomiast u człowieka powoduje groźne uszkodzenie wątroby; środek antydepresyjny - Thalidomid przepisywany kobietom w ciąży doprowadził w latach 50. XX wieku do narodzin 10 tysięcy noworodków bez rąk lub nóg. Środek ten był wcześniej testowany na zwierzętach i został uznany za bezpieczny. Różnica w reakcji organizmów zwierzęcych i ludzkich na ten środek wynikała bowiem z różnic w budowie łożyska u ludzi i zwierząt (Page 2020).

Ponadto różnice te wynikają ze sposobów i środków, jakimi wywołuje się dany stan (np. określone schorzenie), dokonywanych przede wszystkim w warunkach sztucznych - laboratoryjnych, co w rezultacie w znacznym stopniu uniemożliwia uzyskanie analogicznego wyniku, jak w przypadku rozwinięcia się takiego stanu w warunkach naturalnych (Bernard i Kaufman 1997, 62). W tym kontekście należy również zwrócić uwagę, iż także w ramach jednego gatunku występują znaczne rozbieżności 
w funkcjonowaniu organizmu wynikające m.in. z położenia geograficznego, różnic w diecie, cyklu płciowego, stylu życia etc. (Paton 1997, 173). Innym czynnikiem, który według przeciwników wykorzystywania zwierząt $w$ procedurach doświadczalnych generuje rozbieżności w uzyskiwanych wynikach i prowadzi do bezużyteczności prowadzonych w ten sposób badań naukowych, jest stresogenny wpływ środowiska laboratoryjnego. Podnosi się bowiem, że stres wynikający z dotykania przez człowieka zwierzęcia, uwięzienia i jego izolacji może powodować zaburzenia w fizjologii zwierzęcia i wprowadza dodatkowe zmienne doświadczalne (Bernard i Kaufman 1997, 63; Caputa 2017). Za bezcelowością wykorzystywania zwierząt w procedurach doświadczalnych przemawia także okoliczność, że wyniki uzyskane na ich podstawie są jedynie hipotetyczne - dla sprawdzenia ich rzeczywistych właściwości niezbędne jest co do zasady zastosowanie ich na człowieku (Bernard i Kaufman 1997, 64; Paton 1997, 84; Smaga 2010, 172; Goldberg i Hartung 2006, 78; Caputa 2017). Krytyce, jako praktyce zbędnej i nieefektywnej, poddano również procedury doświadczalne $\mathrm{z}$ wykorzystaniem zwierząt w ramach działalności edukacyjnej (Lewis 2000, 75).

Osobny problem stanowi kwestia tworzenia i wykorzystania w procedurach doświadczalnych zwierząt transgenicznych. Charakteryzują się one zmodyfikowanym w określonym kierunku genomem warunkującym pożądane cechy. Umożliwia to zarówno poprawę cech użytkowych zwierząt transgenicznych, jak i wykorzystanie ich dla potrzeb biomedycznych - w tym również ksenotransplantacji (Smorąg i Słomski 2006, 119). Zwierzęta transgeniczne, jako zwierzęta modelowe, odgrywają również istotną rolę w samych procedurach doświadczalnych. Przeciwnicy jednak kreowania takich zwierząt oraz ich wykorzystywania podnoszą, iż w wyniku dokonywanych modyfikacji genetycznych zatarciu ulegają specyficzne potrzeby i cechy danego zwierzęcia, które są determinowane gatunkowo (w tym także zdolność do odczuwania bólu lub cierpienia). W dalszej kolejności prowadzi to zatem do niemożliwości ustalenia, czy dane zwierzę cierpi w poddanych go $\mathrm{w}$ ramach procedury okolicznościach (Verhoog 1998, 215; Linzey 2009, 90).

Z uwagi na zawodność wyników procedur doświadczalnych, w ramach których wykorzystywane są zwierzęta, przeciwnicy tych działań podnoszą również potrzebę zastępowania tych procedur tzw. metodami alternatywnymi. Stanowią one techniki zastępcze, które mogą całkowicie zredukować liczbę wymaganych do badań zwierząt, czy też w znacznym stopniu ograniczyć ból, strach i cierpienie zwierząt doświadczalnych (Radzikowski 1995, 150; Chodorowska 2012, 223). Metody alternatywne pozostają ściśle związane $\mathrm{z}$ realizacją tzw. zasady $3 \mathrm{R}-\mathrm{re}$ placing (zastępowania), refining (osłabiania) oraz reducing (zmniejszania, zredukowania). Zgodnie z pierwszą regułą, zwierzęta kręgowe wykorzystywane w procedurach doświadczalnych powinny być zastępowane zwierzętami bezkręgowymi (które nie mają odpowiednio wykształconego układu nerwowego umożliwiającego im odczuwanie bólu lub cierpienia w stopniu analogicznym do kręgowców) bądź w ogóle wyeliminowane na rzecz stosowania metod alternatywnych - np. hodowli in vitro ( $w$ tym także hodowle tkankowe bądź komórkowe), symulacji komputerowych, doświadczeń na fantomach (modelach fizycznych) o podobnej strukturze, oporności elektrycznej i konsystencji tkanek do wybranych cech organizmu żywego, badania na ludziach- ochotnikach, tzw. mortisekcję - preparatykę zwłok ludzkich bądź zwierzęcych, pracę z martwymi zwierzętami (Piastowska-Ciesielska i Ochędalski 2010, 48; Smaga 2010, 191). Refining polega na ograniczaniu bólu lub cierpienia zwierząt, które zostają poddane procedurom doświadczalnym. Działanie tego typu może polegać w pierwszej kolejności na zaplanowaniu doświadczenia w taki sposób, aby dolegliwości odczuwane przez zwierzę doświadczalne było ograniczone do minimum, bądź w ogóle 
pozbawione elementów bólu, strachu lub stresu. W praktyce powinno przejawiać się to zastosowaniem środków łagodzących, trankwilizujących, miejscowo bądź całkowicie znieczulających. Za przykład realizacji tej metody można uznać także tzw. humanitarne zakończenie badań (humane end point) - przerwanie badań z chwilą uzyskania odpowiednich danych, jeżeli doświadczenie wiąże się z zadawaniem zwierzętom bólu lub cierpienia (Goldberg i Hartung 2006, 75; Piastowska-Ciesielska i Ochędalski 2010, 49). Zgodnie z zasadą reducing, w przypadku gdy metody alternatywne nie pozwalają na zrezygnowanie z konieczności użycia zwierzęcia w eksperymencie, należy dążyć do zmniejszenia liczby zwierząt, które poddawane są doświadczeniu. Zmniejszenie liczby zwierząt może polegać na np. przeprowadzeniu doświadczeń pilotażowych, które umożliwią ustalenie, jakie potencjalne problemy mogą mieć miejsce podczas przeprowadzania właściwego eksperymentu; uzyskaniu jak najwięcej informacji z każdego poddanego doświadczeniu zwierzęcia; minimalizowaniu wpływu zmiennych, które mogą wpłynąć na doświadczenie (m.in. dieta, choroby, stres), wykorzystywanie prześwietleń rentgenowskich, magnetycznego rezonansu jądrowego, czy emisyjnej tomografii pozytonowej etc. (Fox 1986, 125; Giżejewski et al. 2001, 17; Monamy 2000, 81; Goldberg i Hartung 2006, 74; Piastowska-Ciesielska i Ochędalski 2010, 51; Russel and Burch 2020).

\section{Zakończenie}

Problematyka wykorzystywania zwierząt do celów naukowych lub edukacyjnych budzi od lat spore kontrowersje. Pomimo postępującej tendencji do wyeliminowania tego typu praktyk lub przynajmniej ich znacznego ograniczenia (m.in. dzięki wykorzystaniu technik in vitro lub in silico), uwzględniając obecny stan wiedzy, nie jest możliwa całkowita rezygnacja z procedur doświadczalnych, w ramach których wykorzystywane są zwierzęta. Dotyczy to przede wszystkim badań związanych z ochroną życia i zdrowia ludzi bądź innych zwierząt, poznawaniem funkcjonowania organizmów, rozwojem techniki i przemysłu, czy w końcu nabywania umiejętności praktycznych przez osoby kształcące się w danym kierunku. W zaistniałym stanie faktycznym pojawiła się zatem potrzeba znalezienia stosownego kompromisu, który pozwoliłby z jednej strony na zagwarantowanie zwierzętom ich humanitarnego traktowania, z drugiej - umożliwił ich wykorzystanie - w sytuacjach gdy jest to niezbędne. Wyrazem pogodzenia obu tych potrzeb jest kształt obecnych uregulowań prawnych zawartych przede wszystkim ustawie z dnia 21 sierpnia 1997 r. o ochronie zwierząt oraz w ustawie z dnia 15 stycznia 2015 r. o ochronie zwierząt wykorzystywanych do celów naukowych lub edukacyjnych.

Należy w tym miejscu zaznaczyć, że prawo jako nauka społeczna, jest dynamiczne i podlega ciągłemu dostosowywaniu do potrzeb pojawiających się w społeczeństwie. Z tego względu przy tworzeniu stosownych przepisów bierze się pod uwage postulaty zarówno zwolenników, jak i przeciwników danej kwestii oraz przewiduje się rozwiązanie najbardziej optymalne dla społeczeństwa. Ponadto podkreślenia wymaga również okoliczność, że Polska, jako członek Unii Europejskiej, zobowiązana jest także do implementowania odpowiednich przepisów prawa europejskiego - w tym także dotyczących ochrony zwierząt, jak i podejmowania badań z ich udziałem.

Biorąc powyższe pod uwagę, nie można jednoznacznie uznać, że treść obowiązujących norm prawnych została podyktowana wyłącznie jednym z przedstawionych stanowisk związanych z dopuszczalnością lub zakazem podejmowania procedur doświadczalnych z wykorzystaniem zwierząt. Jak już podnoszono, kształtowanie przepisów dotyczących ochrony zwierząt doświadczalnych jest wynikiem pewnego kompromisu pomiędzy koniecznością poszanowania godności zwierzęcia jako istoty żywej, zdolnej do odczuwania negatywnych bodźców, a korzyściami płynącymi z prawidłowo przeprowadzonej procedury, w której zwierzęta 
te są wykorzystywane. Niewątpliwie przepisy prawne zawarte w ustawie o ochronie zwierząt wykorzystywanych do celów naukowych lub edukacyjnych bazują na nadrzędnej normie zawartej w przepisie art. 1 ust. 1 ustawy o ochronie zwierząt, zgodnie z którą zwierzę, jako istota żyjąca, zdolna do odczuwania cierpienia, nie jest rzeczą. Człowiek jest mu winien poszanowanie, ochronę i opiekę. Oznacza to, że wszystkie regulacje odnoszące się do przeprowadzania procedur doświadczalnych z wykorzystaniem zwierząt muszą być podporządkowane tej zasadzie. Jednocześnie dopuszczalne są jednak sytuacje, w których możliwe będzie zadawanie zwierzętom bólu lub cierpienia. Przypadki te muszą jednak wynikać wprost z wyjątków przewidzianych w ustawie (mających odpowiednie uzasadnienie) i przebiegać zgodnie z przyjętą wówczas procedurą. Ustawodawca wprowadził stosowane zasady dotyczące m.in. wyłącznych celów, dla których mogą być przeprowadzane procedury, możliwości stosowania metod badawczych bez wykorzystania zwierząt, ograniczenia ilości osobników poddanych procedurze do poziomu pozwalającego na osiągnięcie pożądanych celów, doboru metod badawczych, dzięki którym możliwe będzie ograniczanie zwierzętom odczuwania negatywnych bodźców. Przewidziano również odpowiednią ścieżkę administracyjną związaną z uzyskaniem zgody na przeprowadzenie danej procedury, a także ramy podejmowanego doświadczenia, podlegające weryfikacji pod kątem zapewnienia ochrony humanitarnej zwierząt. Ma to na celu nie tylko ograniczenie bólu lub cierpienia zwierząt do niezbędnego minimum, lecz także zagwarantowanie możliwie najbardziej dokładnego i wiarygodnego wyniku danej procedury. Naruszenie narzuconych zasad wiąże się z odpowiedzialnością karną (związaną z narażeniem zwierząt doświadczalnych na zbędny ból lub cierpienie) lub administracyjną (dotyczącą zakazu prowadzenia określonej działalności oraz wiążącą się z karami finansowymi).
Zastosowanie właściwego kompromisu co do przyjętej formuły jest widoczne zarówno na etapie tworzenia prawa w przypadku uregulowań dotyczących procedur doświadczalnych z wykorzystaniem zwierząt, jak i późniejszego stosowania ustanowionych norm prawnych. Warto również podkreślić, że na poziomie tworzenia prawa $\mathrm{w}$ danej formie jednym $\mathrm{z}$ etapów jest konsultacja z odpowiednimi podmiotami, które wydają specjalistyczne opinie co do kształtu i zasadności wprowadzenia danego uregulowania (przykładowo w przypadku ustawy o ochronie zwierząt wykorzystywanych do celów naukowych lub edukacyjnych opinie takie sporządzili m.in. przedstawiciel Państwowego Instytutu Weterynaryjnego w Puławach, kierownik Pracowni Hodowli Zwierząt Laboratoryjnych Centrum Onkologii w Warszawie, przedstawiciel Instytutu Genetyki i Biotechnologii Wydziału Biologii Uniwersytetu Warszawskiego). Co więcej, na etapie wykonywania przepisów powyższej ustawy kluczową rolę odgrywa Krajowa Komisja Etyczna do Spraw Doświadczeń na Zwierzętach oraz lokalne komisje etyczne do spraw doświadczeń na zwierzętach. W ich skład, poza przedstawicielami nauk biologicznych, farmaceutycznych, medycznych lub weterynaryjnych, wchodzą bowiem również przedstawiciele nauk humanistycznych - w szczególności z zakresu filozofii, etyki lub prawa i przedstawiciele organizacji społecznych, których statutowym celem działania jest ochrona zwierząt. W ten sposób zagwarantowano konsultację oraz współpracę ze strony osób zajmujących często rozbieżne stanowiska. Pozwala to na zapewnienie optymalnego poziomu ochrony zwierząt, przy jednoczesnej dbałości o jakość prowadzonych procedur doświadczalnych. $\mathrm{Na}$ zakończenie należy dodać, że współpraca członków Krajowej Komisji Etycznej przekłada się również na sam proces tworzenia prawa. Do jej zadań zalicza się bowiem m.in. przedstawianie ministrowi właściwemu do spraw szkolnictwa wyższego i nauki oraz ministrowi właściwemu do spraw rolnictwa wniosków wynikających z rocznego 
sprawozdania podsumowującego wyniki kontroli hodowców, dostawców i użytkowników. Prócz tego jest ona odpowiedzialna za opracowywanie i udostępnianie użytkownikom dobrych praktyk, w szczególności w zakresie planowania i wykonywania procedur, stosowania zasad zastąpienia, ograniczenia i udoskonalenia oraz stosowanych metod alternatywnych. W ten sposób Krajowa Komisja Etyki może wpływać na proces prawodawczy dotyczący ram ochrony zwierząt doświadczalnych, a dzięki różnorodności perspektyw osób wchodzących w jej skład daje gwarancję rozpatrzenia wszystkich spornych aspektów.

\section{Bibliografia}

Achtelik, Aleksandra. 2007. Mitologie świata. Grecja, Rzym i inne starożytne cywilizacje. Katowice: Videograf II.

Bator, Wiesław. 2004. Religia starożytnego Egiptu: perspektywa religioznawcza. Kraków: Wydawnictwo Uniwersytetu Jagiellońskiego.

Bentham, Jeremy. 1958. Wprowadzenie do zasad moralności i prawodawstwa. Warszawa: Polskie Wydawnictwo Naukowe.

Bernard, Neal, i Stephen Kaufman. 1997. „Badania na zwierzętach prowadzą donikąd." Świat Nauki 4: 62-64.

Białocerkiewicz, Jan. 2005. Status prawny zwierzat. Prawa zwierzat czy prawna ochrona zwierzat. Toruń: Towarzystwo Naukowe Organizacji i Kierownictwa Stowarzyszenie Wyższej Szkoły Użyteczności „Dom Organizatora”.

Białocerkiewicz, Jan. 2007. „Stosunek do zwierząt - nowy paradygmat kulturowy w Europie?" W Prawo do życia a jakość życia w wielokulturowej Europie. T. 1. Materiały V Międzynarodowej Konferencji Praw Człowieka (Olsztyn, 2005.05.3031), red. Bronisław Sitek, 93-109. Olsztyn - Bari: Wydział Prawa i Administracji Uniwersytetu Warmińsko-Mazurskiego.

Bieguszewski, Henryk. 2003. Fizjologia zwierzat. Słupsk: Wydawnictwo Pomorskiej Akademii Pedagogicznej.

Bonenberg, Marek. 1992. Etyka środowiskowa. Kraków: Zakład Etyki w Instytucie Filozofii Uniwersytetu Jagiellońskiego.
Botting, Jack, i Adrian Morrison. 1997. „Badania na zwierzętach niezbędne medycynie." Świat Nauki 4: 65-67.

Caputa, Michał. 2017. „W czepku urodzone?!” Dostęp 1.04.2017. http://glos.umk.pl/2001/11/czepek.html. Carruthers, Peter. 1989. "Brute experience." The Journal of Philosophy 86: 505-516.

Chmurzyński, Jerzy. 1995. „Etyczne zasady pracy w naukach behawioralnych." W Eksperymenty na zwierzętach. Wspólna Konferencja Komitetu w Nauce PAN i Komisji Etyki Medycznej PAU, Warszawa 21 listopada 1994 r., red. Elżbieta Fiałek, 39-48. Kraków: Polska Akademia Umiejętności. Chodorowska, Anna. 2012. „Przeprowadzanie doświadczeń na zwierzętach w świetle przepisów prawa polskiego i międzynarodowego." W Prawnokarne i kryminologiczne aspekty ochrony środowiska, red. Wiesław Pływaczewski, 217232. Olsztyn: Katedra Kryminologii i Polityki Kryminalnej na Wydziale Prawa i Administracji Uniwersytetu Warmińsko-Mazurskiego.

DeGrazia, David. 2011. „O byciu osobą poza gatunkiem Homo sapiens." W Wobronie zwierzat, red. Peter Singer, 63-85. Warszawa: Wydawnictwo Czarna Owca.

Dobrucka, Halina. 1995. „Wyzwolenie zwierząt.” W Antologia praw zwierzat, red. Wojciech Owczarz, 41-49. Bielsko-Biała: Klub Gaja.

Donimirski, Andrzej. 1989. Reinkarnacja. Warszawa: Zetpress; Editorex.

Dubinin, Mikołaj. 1998. „Święty Franciszek i jego brat Stońce." Więź 7: 105-112.

Dzierżyńska-Cybulko, Barbara. 1981. „Żywiec rzeźny i jego wstępny przerób." W Technologia mięsa, red. Wincenty Pezacki, 17-70. Warszawa: Wydawnictwo Naukowo-Techniczne.

El-Jai, Julita. 2008. „Stanowisko w etyce środowiskowej wobec doświadczeń na zwierzętach. Część II. Antropocentryzm - koncepcja laicka." Życie Weterynaryjne 83: 38-40.

Epstein, Ronald. 2020. „Prawa zwierząt z buddyjskiej perspektywy." Dostęp 20.06.2020. http://sferadharmy.pl/pl/ prawa-zwierzat-z-buddyjskiej-perspektywy.

Feinberg, Joel. 1980. „Obowiązki człowieka i prawa zwierząt." Etyka 18: 11-38.

Ferry, Luc. 1995. Nowy tad ekologiczny. Drzewo, zwierze $i$ człowiek. Warszawa: Centrum Uniwersalizmu przy Uniwersytecie Warszawskim: 
Polski Oddział Międzynarodowego Towarzystwa Uniwersalizmu.

Fox, Michael. 1986. Laboratory animal husbandry. Ethology, Welfare and Experimental Variables. New York: State University of New York Press.

Francuz, Grzegorz. 2012. Strategie przypisywania statusu moralnego istotom żywym. Opole: Wydawnictwo Uniwersytetu Opolskiego.

Gądzik, Zuzanna. 2018. Prawnokarna ochrona zwierzat wykorzystywanych $w$ procedurach doświadczalnych. Lublin: Wydawnictwo KUL.

Giżejewski, Zygmunt, Zbigniew Hull, Stefan Kasicki, Franciszek Przała, i Zenon Zduńczyk. 2001. Etyczne i prawne uwarunkowania wykorzystania zwierzat w pracy dydaktycznej $i$ badaniach naukowych: informator Lokalnej Komisji Etycznej do Spraw Doświadczeń na Zwierzętach w Olsztynie. Olsztyn: Wydawnictwo UWM.

Goldberg, Alan, i Thomas Hartung. 2006. „Na ratunek królikom doświadczalnym." Świat Nauki 3: 70-78.

Griffin, Donald. 2004. Umysty zwierząt. Czy zwierzęta mają świadomość? Gdańsk: Gdańskie Wydawnictwo Psychologiczne.

Gzyra, Dariusz. 2012. „Teoria praw zwierząt Toma Regana.” W Status zwierzecia. Zagadnienia filozoficzne i prawne, red. Teresa Gardocka, i Agnieszka Gruszczyńska, 43-60. Toruń: Wydawnictwo Adam Marszałek.

Hallam, Elisabeth. 1999. Bogowie i boginie: ponad 130 postaci bóstw $w$ religiach świata. Warszawa: Diogenes.

Hoff, Christine. 1980. „Kilka refleksji moralnych o eksperymentach na zwierzętach." Etyka 18: 63-76.

Janik, Czesław. 2012. „Status zwierzęcia w głównych systemach religijnych." W Status zwierzecia. Zagadnienia filozoficzne i prawne, red. Teresa Gardocka, i Agnieszka Gruszczyńska, 77-104. Toruń: Wydawnictwo Adam Marszałek.

Kant, Immanuel. 1953. Uzasadnienie metafizyki moralności. Warszawa: Państwowe Wydawnictwo Naukowe.

Kartezjusz, René. 1994. Rozprawa o metodzie. Warszawa: Agencja Wydawnicza MOREX.

Kasicki, Stefan. 1995. „Stop eksperymentom?” Wszechświat 10: 257-260.

Kluba, Eligiusz. 1965. Z dawnych wierzeń indyjskich. Warszawa: Książka i Wiedza.
Koehler, Witold. 1981. Zwierzęta czekają. Warszawa: Krajowa Agencja Wydawnicza.

Kozłowski, Tomasz. 2012. „Wyzwolenie prawa prawość i prawna ochrona zwierząt." W Status $z$ wierzęcia. Zagadnienia filozoficzne i prawne, red. Teresa Gardocka, i Agnieszka Gruszczyńska, 121-152. Toruń: Wydawnictwo Adam Marszałek. Lazari-Pawłowska, Ija. 1976. Schweitzer. Warszawa: Wiedza Powszechna.

Lewis, Karen. 2000. “Animal experimentation in education is unethical." In Animal experimentation, edited by David Haugen, 75-77. San Diego: Greenhaven Press.

Linzey, Andrew. 2009. „Inżynieria genetyczna jako zwierzęce niewolnictwo." Konteksty 287: 90-99.

Liszewski, Dariusz, i Zenon Zduńczyk. 2013. „Etyka i prawo a doświadczenia na zwierzętach w postępie zdrowia publicznego." W Zwierzęta laboratoryjne patologia $i$ użytkowanie, red. Józef Szarek, Magdalena Szweda, i Emilia Strzyżewska 15-32. Olsztyn: Wydawnictwo Uniwersytetu Warmińsko-Mazurskiego.

Locke, John. 1959. Myśli o wychowaniu. Wrocław - Kraków: Zakład Narodowy im. Ossolińskich.

Łapiński, Jacek. 2002. „Etyczne podstawy prawnej ochrony zwierząt." Studia z Prawa Wyznaniowego 4: 141-162.

Majewski, Andrzej. 2000. „Aksjologiczne podstawy prawnej ochrony zwierząt w aspekcie humanitarnym." Gdańskie Studia Prawnicze 7: 365-380.

Majewski, Andrzej. 2002. „Dopuszczalność przeprowadzania w celach dydaktycznych doświadczeń na zwierzętach w prawie polskim." Zeszyty Naukowe Szkoły Wyższej im. Pawła Włodkowica w Płocku 21: 223-236.

Masson, Jeffrey, i Susan McCarthy. 1999. Kiedy słonie płacza. O życiu emocjonalnym zwierzat. Warszawa: Książka i Wiedza.

Matheny, Gaverick. 2011. „Utylitaryzm i zwierzęta.” W W obronie zwierzat, red. Peter Singer, 24-43. Warszawa: Wydawnictwo Czarna Owca.

Michna, Gustaw. 2001. „Ochrona zwierząt w aspekcie humanitarnym i prawnym.” Aura 8: 4-6.

Monamy, Vaughan. 2000. Animal experimentation. A guide to the issues. Cambridge: Cambridge University Press.

Mroczkowski, Sławomir, i Anna Frieske. 2014. Prawne i etyczne aspekty inżynierii biomedycznej. 
Eksperymenty na zwierzętach $i$ badania kliniczne wyrobów medycznych. Bydgoszcz: Wydawnictwa Uczelniane Uniwersytetu Technologiczno-Przyrodniczego.

Olędzka, Agnieszka. 1995. „Wegetariański świat.” W Antologia praw zwierzat, red. Wojciech Owczarz, 111-115. Bielsko-Biała: Klub Gaja.

Page, Tony. 2020. „Wiwisekcja - nienaukowy nonsens." Dostęp: 20.06.2020. https://psy24.pl/psy-w-potrzebie,ac107/ wiwisekcja-nienaukowy-nonsens, 1047.

Paton, William. 1997. Człowiek i mysz: badania medyczne na zwierzetach. Warszawa: Wydawnictwo Naukowe PWN.

Piastowska-Ciesielska, Agnieszka, i Tomasz Ochędalski. 2010. Metodyka badań in vivo materiaty dydaktyczne dla studentów kierunku biotechnologia specjalność biotechnologia medyczna. Łódź: Uniwersytet Medyczny w Łodzi, Wydział Nauk Biomedycznych i Kształcenia Podyplomowego.

Piątek, Zdzisława. 1998. Etyka środowiskowa. Kraków: Księgarnia Akademicka.

Pietrzykowski, Tomasz. 2007. Spór o prawa zwierząt. Katowice: Wydawnictwo Sonia Draga.

Prost, Edmund. 2006. Zwierzęta rzeźne i mięso ocena $i$ higiena. Lublin: Lubelskie Towarzystwo Naukowe.

Przała, Franciszek. 2005. „Kryteria dopuszczalności użycia zwierząt do badań naukowych i dydaktyki." Forum Teologiczne 6: 65-74.

Rada Ministrów. 2020. Projekt ustawy o zmianie ustawy o ochronie zwierzat wykorzystywanych do celów naukowych lub edukacyjnych. Dostęp 18.08.2020. https://bip.kprm.gov.pl/kpr/biprady-ministrow/prace-legislacyjne-rm-i/pracelegislacyjne-rady/wykaz-prac-legislacyjny/ r802845, Projekt-ustawy-o-zmianie-ustawyo-ochronie-zwierzat-wykorzystywanych-docelow-na.html.

Radzikowski, Czesław. 1995. „Ocena tzw. metod alternatywnych w badaniach biomedycznych." Nauka 1: 150-157.

Regan, Tom. 1980. „Prawa i krzywda zwierząt.” Etyka 18: 87-118.

Regan, Tom. 2004a. Empty Cages: Facing the challenge of animal rights. Lonham: Rowman and Littlefield Publishers.
Regan, Tom. 2004b. The Case for Animal Rights. Berkley: University of California Press.

Russell, William, and Rex Burch. 2020. "The Principles of Humane Experimental Technique (chapter 6 - Reduction)." Dostęp 21.06.2020. https://caat.jhsph.edu/principles/chap6a.

Ryder, Richard. 1980. „Szowinizm gatunkowy, czyli etyka wiwisekcji." Etyka 18: 39-47.

Ryder, Richard. 2011. „Szowinizm gatunkowy w laboratorium." W W obronie zwierzat, red. Peter Singer, 128-151. Warszawa: Wydawnictwo Czarna Owca.

Schopenhauer, Artur. 2004. O podstawie moralności. Kraków: Zielona Sowa.

Singer, Peter. 1980. „Zwierzęta i ludzie jako istoty równe sobie." Etyka 18: 49-62.

Singer, Peter. 2004. Wyzwolenie zwierzat. Warszawa: Państwowy Instytut Wydawniczy.

Smaga, Łukasz. 2010. Ochrona humanitarna zwierzat. Białystok: Agencja WydawniczoEdytorska EkoPress.

Smorąg, Zdzisław, i Ryszard Słomski. 2006. „Biotechnologia, klonowanie, transgeniczne zwierzęta, ksenotransplantacja." Arcana; kultura, historia, polityka 69: 118-123.

Szabała, Henryk. 1998. O filozofii sprzeciwu czyli o antropocentryzmie $w$ dziejach filozofii. Gdańsk: Wydawnictwo Uniwersytetu Gdańskiego.

Tokarczyk, Andrzej. 1986. Hinduizm. Warszawa: Krajowa Agencja Wydawnicza.

Tomasz z Akwinu. 1985. Suma teologiczna, t. 13. Londyn: Veritas.

Verhoog, Henk. 1998. „Moralność a «naturalność» zwierząt transgenicznych." Ethos 44: 215-227.

Vetulani, Jerzy. 1995. „Skąd bierze się potrzeba humanitarnego traktowania zwierząt laboratoryjnych?" W Eksperymenty na zwierzętach. Wspólna Konferencja Komitetu w Nauce PAN i Komisji Etyki Medycznej PAU, Warszawa 21 listopada 1994 r., red. Elżbieta Fiałek, 7-10. Kraków: Polska Akademia Umiejętności.

Waldau, Paul. 2011. „Religia i zwierzęta.” W Wobronie zwierzat, red. Peter Singer, 105-125. Warszawa: Wydawnictwo Czarna Owca.

Woleński, Jan. 2012. „Podmiotowość zwierząt w aspekcie filozoficznym." W Status zwierzęcia. Zagadnienia filozoficzne i prawne, red. Teresa Gardocka, i Agnieszka Gruszczyńska, 11-28. Toruń: Wydawnictwo Adam Marszałek. 
Załucki, Grzegorz, i Wojciech Zawadzki. 2005. „Układ nerwowy i narządy zmysłów.” W Fizjologia zwierzat, red. Tadeusz Krzymowski, i Jadwiga Przała, 17-129. Warszawa: Państwowe Wydawnictwo Rolnicze i Leśne.

Zięba, Stanisław. 1993a. „Człowiek a świat zwierząt (cz. I)." Przeglad Hodowlany 2: 29.

Zięba, Stanisław. 1993b. „Człowiek a świat zwierząt (cz. II)." Przeglad Hodowlany 3: 22-24. 